\title{
Enhancing Livelihood Security in Arid Land through Use of Bio-pesticides in Cumin(Cuminum cyminum L.)
}

\author{
Bhagwan Singh*, A.K. Sharma \\ Division of Transfer of Technology, Training and Production Economics, Central Arid Zone Research Institute, India
}

Copyright $\subset 2016$ by authors, all rights reserved. Authors agree that this article remains permanently open access under the terms of the Creative Commons Attribution License 4.0 International License

\begin{abstract}
Assessment of the use of improved varieties of cumin (RZ-209 and GC-4) along with treatments of two low cost ecofriendly biopesticides, i.e. soil application of neem cake (NC) and seed treatment with Aspergillus versicolor (Av) were conducted in the farmer's fields at 65 locations in Bheenjwadia village Jodhpur district during rabi seasons of 2010 to 2013. Application of $\mathrm{NC}$ in improved variety, increased seed yield by 16.85 and $20.73 \%$ in GC-4 and RZ-209 respectively, over control. Similarly, seed yield of cumin was obtained $18.77 \%$ higher due to use of NC in local variety. Use of neem cake in improved and local variety of cumin provided Rs.3466, Rs.3400 and Rs.5300/ha in local, GC-4 and RZ-209 as net returns over control. A net returns was obtained Rs. 2627, Rs.2110 and Rs. 2193/ha in local, GC-4 and RZ-209 respectively due to seed treatment with Av. as compared to control.
\end{abstract}

Keywords Cumin, Neem Cake, Aspergillus Versicolor

\section{Introduction}

Cumin is a low water requiring high value crop of arid zone having export of Rs 200 million year ${ }^{1}$. It occupies about 4.95 lakh ha area with total production of 1.76 lakh tones (2012-13) in Rajasthan. The average productivity of cumin is very low (356 $\left.\mathrm{kg} \mathrm{ha}^{-1}\right)$ as compared to its potentiality $(850 \mathrm{~kg}$ $\mathrm{ha}^{-1}$ ) in Rajasthan. Being high value export crop quality production is highly desirable. However, due to high use of pesticide like organo-phosphate and others the residue in the produce is becoming major constraint for export. Therefore, the study was conducted in a village Bheenjwadia of Jodhpur district to produce cumin with the use of bio-pesticides i.e. neem cake and Aspergillus versicolor (brand name Marusena).A. versicolor has been reported as effective wilt control bio-agent by various researchers Deepak and Lal
[1],Singh et al. [2] and Singh et al.[3].

\section{Material and Methods}

Assessment of the use of improved varieties of cumin (RZ-209 and GC-4) along with neem cake (NC) of 3.5\% oil content and seed treatment with Aspergillus versicolor were conducted at the farmer's fields at 65 locations in Bheenjwadia village Jodhpur district during rabi seasons of 2010-11 to 2012-13. Treatment set one of bio-pesticides i.e. neem cake was applied @ $400 \mathrm{~kg} \mathrm{ha}^{-1}$ at the time of last ploughing in and were compared with control. Neem cake has been reported by various workers Kimaru et. al. [4] and Singh et.al. [5] as an effective material for controlling fungal diseases. Treatment set two of bio-pesticides i.e. seed was treated with bio-control agent Aspergillus versicolor@6 $\mathrm{g} / \mathrm{kg}$ seed before sowing and were compared with control.

\section{Results and Discussion}

\section{Effect of Neem Cake on Seed Yield of Cumin}

The mean seed yield of cumin varieties GC-4 and RZ-209 was obtained $498.50 \mathrm{kgha}^{-1}$ and $524.33 \mathrm{kgha}^{-1}$ respectively. Application of NC @ $400 \mathrm{kgha}^{-1}$, seed yield of cumin varieties GC-4 and RZ-209 was recorded $582.50 \mathrm{kgha}^{-1}$ and $627.33 \mathrm{kgha}^{-1}$ respectively. Application of $\mathrm{NC}$ in improved variety, increased seed yield by 16.85 and $19.64 \%$ in GC-4 and RZ-209 respectively, over control (Table-1). The mean seed yield of local variety was obtained 451.00 $\mathrm{kgha}^{-1}$.Application of $\mathrm{NC}$ in local variety; seed yield was recorded $535.66 \mathrm{~kg} \mathrm{ha}^{-1}$. The seed yield of cumin was $18.77 \%$ higher due to use of NC in local variety. Use of neem cake in improved and local variety of cumin provided Rs.3466, Rs.3400 and Rs.5300 ha $^{-1}$ in local, GC-4 and RZ-209 respectively as net returns with this treatment only, over control (Table 1) with the investment of Rs. 5000 only. 
Table 1. Effect of variety and neem cake on the net returns in cumin (2010-11 to 2012-13)

\begin{tabular}{|c|c|c|c|c|c|}
\hline Treatments & $\begin{array}{c}\text { Seed } \\
\text { yield } \\
\mathrm{kg} \mathrm{ha}^{-1}\end{array}$ & \% yield increase & $\begin{array}{c}\text { Yield } \\
\text { increased over the } \\
\text { treatment } \\
\left(\mathrm{Kg} \mathrm{ha}^{-1}\right)\end{array}$ & $\begin{array}{c}\text { Cost of treatment } \\
\left(\mathrm{Rs} \mathrm{ha}^{1}\right)\end{array}$ & $\begin{array}{c}\text { Net returns with } \\
\text { the treatment of } \\
\text { neem cake only } \\
\left(\mathrm{Rs}^{-1}\right)^{-1}\end{array}$ \\
\hline Local & 451.00 & - & - & - & - \\
\hline Local + neem cake & 535.66 & 18.77 & 84.66 & 5000 & 3466 \\
\hline GC-4 & 498.50 & - & - & - & - \\
\hline GC-4 + neem cake & 582.50 & 16.85 & 84 & 5000 & 3400 \\
\hline RZ-209 & 524.33 & - & - & - & - \\
\hline RZ-209 + neem cake & 627.33 & 19.64 & 103 & 5000 & 5300 \\
\hline
\end{tabular}

Note : Price of cumin Rs. $100 \mathrm{~kg}^{-1}$

Table 2. Effect of marusena (Aspergillusversicolor) on the net returns in cumin crop (2010-11 to 2012-13)

\begin{tabular}{|c|c|c|c|c|c|}
\hline Treatments & $\begin{array}{c}\text { Seed } \\
\text { yield } \\
\mathrm{kg} \mathrm{ha}^{-1}\end{array}$ & $\begin{array}{c}\text { \% yield } \\
\text { increase }\end{array}$ & $\begin{array}{c}\text { Yield } \\
\text { increased over the } \\
\text { treatment }(\mathrm{Kg} \\
\left.\mathrm{ha}^{-1}\right)\end{array}$ & $\begin{array}{c}\text { Cost of } \\
\text { treatment } \\
\left(\mathrm{Rs} \mathrm{ha}^{-1}\right)\end{array}$ & $\begin{array}{c}\text { Net returns with the } \\
\text { treatment of } \\
\text { marusena only } \\
\left(\mathrm{Rs.} \mathrm{ha}^{-1}\right)\end{array}$ \\
\hline Local & 443.33 & - & $=$ & $=$ & - \\
\hline Local + Marusena treatment & 470.00 & 6.01 & 26.67 & 40 & 2627 \\
\hline GC-4 & 493.50 & - & - & - & - \\
\hline GC-4 + Marusena treatment & 515.00 & 4.35 & 21.50 & 40 & 2110 \\
\hline RZ-209 & 497.00 & - & - & - & - \\
\hline RZ-209 + Marusena treatment & 519.33 & 4.49 & 22.33 & 40 & 2193 \\
\hline
\end{tabular}

Note: Price of cumin Rs. $100 \mathrm{~kg}^{-1}$

\section{Effect of Marusena (Aspergillus Versicolor) on Seed Yield of Cumin}

The data presented in Table 2 revealed that mean seed yield of cumin varieties GC-4 and RZ-209 was obtained $493.50 \mathrm{~kg} \mathrm{ha}^{-1}$ and $497.00 \mathrm{kgha}^{-1}$ respectively. Seed treatment with marusena, seed yield of cumin varieties GC-4 and RZ-209 was recorded $515 \mathrm{~kg} \mathrm{ha}^{-1}$ and $519.33 \mathrm{~kg}$ $\mathrm{ha}^{-1}$ respectively with. Seed yield increased by 4.35 and $4.49 \%$ in GC-4 and RZ-209 respectively due to seed treatment with marusena, over control (Table-2). The mean seed yield of local variety was obtained $470.00 \mathrm{kgha}^{-1}$ with seed treatment with marusena as compared to $443.33 \mathrm{~kg} \mathrm{ha}^{-1}$ in control. A net returns with this treatment only, was obtained Rs.2627, Rs.2110 and Rs.2193ha ${ }^{-1}$ in local, GC-4 and RZ-209 respectively due to seed treatment with marusena as compare to control(Table 2) with the investment of Rs 40 only.

Farmers showed favorable to most favorable attitude about technologies. These eco-technologies not only cost effective, easily applicable but also enhanced export possibilities due to pesticide free produce.

\section{Conclusions}

It can be concluded that application of neem cake (NC) in improved variety, increased seed yield by 16.85 and $19.64 \%$ in GC-4 and RZ-209 respectively, over control. Similarly, seed yield of cumin was obtained $18.77 \%$ higher due to use of NC in local variety. Seed treatment of cumin varieties with Aspergillus versicolor (brand name marusena), increased seed yield by $4.35,4.49$ and 6.01 per cent in GC-4, RZ-209 and local respectively. Use of neem cake in improved and local variety of cumin provided Rs.3466, Rs.3400 and Rs.5300 ha ${ }^{-1}$ in local, GC-4 and RZ-209 as net returns over control with the investment of Rs.5000. A net returns was obtained Rs.2627, Rs.2110 and Rs.2193ha ${ }^{-1}$ in local, GC-4 and RZ-209 respectively due to seed treatment with marusena as compared to control with the investment of Rs 40 only. Therefore, both the inputs are ecologically and economically viable for using in cumin crop production.

\section{REFERENCES}

[1] Deepak and Lal G.2009.Integrated strategy to control wilt disease of cumin (Cuminum cyminum L.) caused by Fusarium oxysporum f. sp. cumini (Schlecht) Prasad \& Patel. Journal of Spices and Aromatic Crops; 18 (1) :13-18.

[2] Singh, V., Mawar, R and Lodha, S. 2012. Combined effect of bio-control agents and soil amendments on soil microbial populations, plant growth and incidence of charcoal rot on cowpea and wilt on cumin. Phytopathologia Mediterranea 51 (2): 307-316.

[3] Singh, V., Mawar, R and Lodha, S. 2014. Influence of bio-ecological factors on population dynamics of a native bio 
control agent Aspergillus versicolor in arid soil. Indian phytopathology 67: 86-91.

[4] Kimaru S. K., Waudo S. W., Monda E., Seif A. A. and Birgen J.K.2004. Effect of Neem Kernel Cake Powder (NKCP) on Fusarium Wilt of Tomato when Used as Soil Amendment Journal of Agriculture and Rural Development in the Tropics and Subtropics Volume 105, No.1, 2004, pages 63-69.
[5] Singh Ravindra , Biswas S. K., Nagar D., Singh J., Singh M and Mishra Y K .2015. Sustainable integrated Approach for Management of Fusarium Wilt of Tomato Caused by Fusarium oxysporum f. sp. lycopersici (Sacc.) Synder and Hansen. Sustainable Agriculture Research; 4(1) Published by Canadian Center of Science and Education. 138-142. 